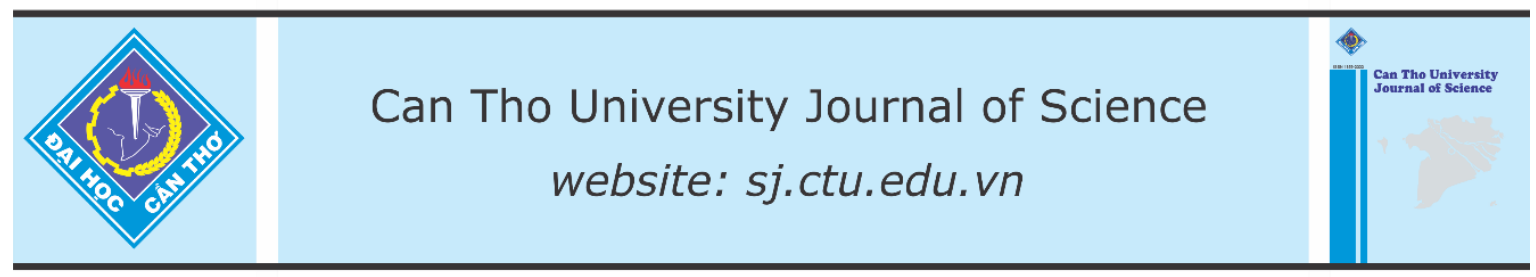

DOI: $10.22144 /$ ctu.jen.2021.015

\title{
Effects of rotifer densities on larval performance of spotted scat (Scatophagus argus)
}

\author{
Le Quoc Viet ${ }^{1 *}$, Ly Van Khanh ${ }^{1}$, Duong Thi My Han ${ }^{1}$, Tran Nguyen Duy Khoa ${ }^{1}$, \\ Kotani Tomonari ${ }^{2}$ and Tran Ngoc $\mathrm{Hai}^{1}$ \\ ${ }^{1}$ College of Aquaculture and Fisheries, Can Tho University, Viet Nam \\ ${ }^{2}$ Faculty of Fisheries, Kagoshima University, Japan \\ *Correspondence: Le Quoc Viet (email: quocviet@ctu.edu.vn)
}

\section{Article info.}

Received 22 Feb 2021

Revised 30 May 2021

Accepted 04 Jun 2021

\section{Keywords}

Growth performance, rotifer feeding density, Scatophagus argus

\begin{abstract}
This study is aimed to determine the optimal rotifer feeding density for larviculture of spotted scat fish (Scatophagus argus). The experiment was randomly set up in triplicate with 5 treatments including 5, 10, 15, 20 and 25 rotifers $/ m L$. The fish larvae with the initial body length and depth at $2,343 \pm 110 \mu \mathrm{m}$ and $812 \pm 85 \mu \mathrm{m}$, respectively, were stocked in 250-L tanks at 10 larva/L of density and 25\% of salinity. After 21 days of rearing, the results showed that the larval growth were at $243-330 \mu \mathrm{m} /$ day of $D L G$ and $5.50-6.70 \% /$ day of SGRL; $131-204 \mu \mathrm{m} /$ day of DDG and $7.20-8.93$ $\% / d a y$ of SGRD, but no significant difference in larval growth performance was recorded among treatments ( $p>0.05)$. However, the highest survival rate of fish larvae (35.4-48.1\%) was recorded in the treatments fed 5 and 10 rotifers $/ \mathrm{mL}$ and was significantly higher than other treatments $(p<0.05)$. The data demonstrated that spotted scat larvae fed effectively across as wide range of rotifer densities and the range at 5-10 rotifers $/ \mathrm{mL}$ were suggested for the husbandry practices.
\end{abstract}

\section{INTRODUCTION}

First exogenous feeding success is critical to larval marine finfish and the use of live feeds remains essential in hatcheries (Wikfors, 2004; Woolley \& Partridge, 2016). In which, rotifer, Artemia, and copepod are typically used in feeding larvae due to their small size, high nutrient values (Wikfors, 2004). Rotifers (Brachionus sp.) were considered as a valuable live feed for feeding for initial stages of fish (Dhert et al., 2001). The small size, ability to stay in the water column, high reproductive rate and their capability to be cultured at large volumes made them a proper starter prey for most cultured fish and shellfish (Lubzens et al., 1989; Kandathil et al., 2020). Traditionally, the live prey are maintained in the cultured systems at high density to ensure the food is never limited and fish larvae fed satisfied
(Fielder, 2013). Disadvantages of this practice, however, include a potential degradation of the rotifer nutritional value with increasing rotifer residence times and the increased potential for bacterial blooms and deterioration of water quality as a result of continued high rotifer densities (Vallés et al., 2015; Woolley \& Partridge, 2016). Moreover, high consumption of live feeds be associated with higher production costs (Rabe \& Brown, 2000). Therefore, the optimizations of feeding regimes including feeding frequency, live feed density are important for larval performance and hatchery production cost.

Spotted scat (Scatophagus argus) is a euryhaline teleost, which is widely distributed in Indo Pacific, South and South East Asia (Gupta, 2016). Due to their attractive pattern and high nutrient quality, this fish has high demand as aquarium fish and food fish 
(Shao et al., 2004). However, the $S$. argus fry and juvenile were mainly harvested from the wild, which threatens the natural resources ( $\mathrm{Su}$ et al., 2019). In Vietnam, spotted scat was integrative stocked in extensive shrimp ponds to prevent overgrowth of algae and seaweeds as well as improve water quality (Viet et al., 2020). Some studies have developed protocols for artificial breeding of this species with promising results (Khanh et al., 2010; Khanh et al., 2014). This study proposes to evaluate the effects of rotifer feeding density on the growth performance and survival rate of $S$. argus larvae for the feeding regime optimization.

\section{METHODS}

\subsection{Experimental design}

Larvae of S. argus were obtained from the Marine hatchery, Can Tho University. After hatching, the active larvae were collected, then randomly stocked in $250 \mathrm{~L}$ tanks at 10 larvae /L with continuous aeration and $25 \%$ of salinity. Five treatments of rotifer density (including 5, 10, 15, 20, and 25 ind./L) were evaluated in triplicate. The initial larvae sizes were recorded at 2,343 $\pm 110 \mu \mathrm{m}$ of total length and 812 $\pm 85 \mu \mathrm{m}$ of body depth. Larvae were fed with enriched rotifer from day 3 to day 15 after hatching (DAH). Rotifers (Brachionus rotundiformis) enriched with DHA PROTEIN SELCO (INVE, Belgium) for $12 \mathrm{~h}$ were added to rearing tanks twice a day at $8 \mathrm{AM}$ and $3 \mathrm{PM}$. After enrichment, rotifers were harvested into $20 \mathrm{~L}$ tank and estimated the density, then distributed to the rearing tanks. From day 12, larvae were alternatively fed with Artemia nauplii enriched with A1 DHA SELCO (for $12 \mathrm{~h}$ ). The Artemia nauplii were added to rearing tanks twice a day at 8:30 AM and 3:30 PM at 1-2 ind./L. Chlorella $\mathrm{sp}$. was daily supplied to the rearing tanks at $10^{3}$ $10^{4}$ cells $/ \mathrm{mL}$. Water exchange and siphon were done every 3 days at $30 \%$ rearing volume. The experiment lasted for 21 days.

\subsection{Sampling}

Water quality parameters: Twice a day (at $7 \mathrm{AM}$ and $2 \mathrm{PM}$ ), temperature, and $\mathrm{pH}$ were monitored using a digital meter (HI-98196 Multi-Parameter Waterproof Meter, HANNA Instruments, Ltd.). Dissolved oxygen (DO) was checked every 3 days using OXY Guard meter. Total ammonium nitrogen (TAN), nitrite and alkalinity were weekly measured using Sera test kits (Germany) at 8 AM. Light intensity was determined at $6 \mathrm{AM}, 9 \mathrm{AM}, 12 \mathrm{AM}, 3 \mathrm{PM}$, and 6 PM using Testo 545.
Fish: Before stocking, the initial size of larvae was randomly recorded by measuring 10 larvae. Every 10 days, the sampling was randomly conducted, wherein 10 fishes per tank were individually measured body weight and total length. At the end of the experiment, 10 fishes from each tank were measured to determine daily weight gain (DWG), specific growth rate (SGR), daily length gain (DLG) and specific growth rate in length (SGRL), daily body depth gain (DDG) and specific growth rate in body depth (SGRD) as follows:

$$
\text { DLG }=\frac{\text { Final length }- \text { Initial length }}{\text { Day of culture }}
$$

$$
\begin{aligned}
& \text { SGRL }(\%) \\
& =\frac{100 *(\text { Ln Final length }- \text { Ln Initial length })}{\text { Day of culture }} \\
& \text { DDG }=\frac{\text { Final depth }- \text { Initial depth }}{\text { Day of culture }} \\
& \text { SGRD }(\%) \\
& =\frac{100 *(\text { Ln Final depth }- \text { Ln Initial depth })}{\text { Day of culture }}
\end{aligned}
$$

The survival rate (SR) of fish was estimated after 21 days of rearing:

$$
\text { SR }(\%)=\frac{\text { Final stock } * 100}{\text { Inital stock }}
$$

\subsection{Data analysis}

Data were presented as mean \pm standard deviation (SD) and were subjected to one-way ANOVA (SPSS 16.0 for Windows, IBM, Armonk, NY, USA), and Duncan's test was applied ( $\mathrm{p}<0.05)$.

\section{RESULTS AND DISCUSSION}

\subsection{Water quality}

\subsubsection{Temperature, $\mathrm{pH}$ and $\mathrm{DO}$}

Temperature during the experimental period ranged from 27.3 to $30.5^{\circ} \mathrm{C}$ (Table 1). According to Boyd (1998), the optimal temperature for tropical fishes was suggested from $26-30^{\circ} \mathrm{C}$. Previous studies highlighted that temperature is a critical factor and should maintained stably during the larval rearing due to its significant effects on survival, nutrient intake and metabolism processes in fishes (Brest et al., 1996; McCarthy et al., 1998; Claireaux et al., 2006).

$\mathrm{pH}$ value fluctuated from 8.2 to 8.5 and $\mathrm{DO}$ was from 5.2 to $6.0 \mathrm{mg} / \mathrm{L}$. For fish hatchery, the DO level at least $4 \mathrm{mg} / \mathrm{L}$ and $\mathrm{pH}$ from $7.5-8.7$ were suggested to obtain good survival and performance of 
the larvae (Jayakumar \& Nazar, 2013; Sim et al., 2005; Moretti et al., 2005). Generally, the water physical parameters were not significantly different

Table 1. Temperature, $\mathrm{pH}$ and DO in five treatments

\begin{tabular}{crrrrrr}
\hline Treatment (Rotifer denstity, & \multicolumn{2}{c}{ Temperature $\left({ }^{\circ} \mathbf{C}\right)$} & \multicolumn{2}{c}{ pH } & \multicolumn{2}{c}{ DO $(\mathbf{m g} / \mathbf{L})$} \\
\cline { 2 - 7 } ind./mL) & AM & PM & AM & PM & AM & PM \\
\hline 5 & $27.4 \pm 0.5$ & $30.3 \pm 0.5$ & $8.3 \pm 0.1$ & $8.5 \pm 0.1$ & $5.2 \pm 0.4$ & $5.9 \pm 0.7$ \\
10 & $27.3 \pm 0.5$ & $30.5 \pm 0.4$ & $8.2 \pm 0.1$ & $8.5 \pm 0.1$ & $5.3 \pm 0.4$ & $6.0 \pm 0.7$ \\
15 & $27.4 \pm 0.6$ & $30.5 \pm 0.5$ & $8.2 \pm 0.1$ & $8.4 \pm 0.1$ & $5.2 \pm 0.4$ & $5.8 \pm 0.6$ \\
20 & $27.4 \pm 0.5$ & $30.5 \pm 0.8$ & $8.3 \pm 0.1$ & $8.4 \pm 0.1$ & $5.2 \pm 0.4$ & $5.8 \pm 0.6$ \\
25 & $27.3 \pm 0.5$ & $30.5 \pm 0.5$ & $8.2 \pm 1.1$ & $8.4 \pm 0.2$ & $5.2 \pm 0.4$ & $5.9 \pm 0.6$ \\
\hline
\end{tabular}

Mean \pm standard deviation

\subsubsection{Light intensity}

Light intensity daily fluctuated from 117 to 14,448 lux (Table 2) and no significant difference among treatments was recorded $(\mathrm{p}>0.05)$. According to Batty et al. (1990) and Didrikas \& Hansson (2009), among treatments and were in a suitable range for normal development of fish.

Table 2. Fluctuation of daylight intensity

\begin{tabular}{crrrrr}
\hline Treatment (Rotifer & \multicolumn{5}{c}{ Light intensity (lux) } \\
\cline { 2 - 6 } denstity, ind./mL) & 6 AM & 9 AM & 12 AM & 3 PM & 6 PM \\
\hline 5 & $158 \pm 24$ & $4,991 \pm 718$ & $13,606 \pm 1,906$ & $12,338 \pm 3,495$ & $117 \pm 30$ \\
10 & $190 \pm 13$ & $6,975 \pm 985$ & $14,214 \pm 1,184$ & $12,589 \pm 4,332$ & $127 \pm 27$ \\
15 & $182 \pm 32$ & $7,395 \pm 502$ & $14,190 \pm 2,334$ & $12,318 \pm 4,883$ & $124 \pm 33$ \\
20 & $172 \pm 45$ & $6,135 \pm 992$ & $13,572 \pm 1,290$ & $11,306 \pm 2,798$ & $120 \pm 43$ \\
25 & $188 \pm 23$ & $7,204 \pm 973$ & $14,448 \pm 1,339$ & $12,131 \pm 1,646$ & $136 \pm 26$ \\
\hline
\end{tabular}

Mean \pm standard deviation

\subsubsection{TAN, nitrite and alkalinity}

TAN concentration ranged from 0.6 to $0.7 \mathrm{mg} / \mathrm{L}$, nitrite was from 1.0 to $1.2 \mathrm{mg} / \mathrm{L}$ and alkalinity was maintained within 112-117 $\mathrm{mg} \mathrm{CaCO}_{3} / \mathrm{L}$ (Table 3), and there was no significant difference in TAN, nitrite and alkalinity level among treatments. Barry and Fast (1992) reported that spotted scat strongly tolerated to critical conditions such as poor water most pelagic fish are visual predators, and their behavior and activity are strongly affected by the diel light cycle. The fish larvae adapted well to the 12 dark: 12 light cycle, and the light intensity within 50-10000 lux should maintain for the fish hatchery (Villamizar et al., 2011).

Table 3. TAN, nitrite and alkalinity concentration in five treatments

\begin{tabular}{crrr}
\hline $\begin{array}{c}\text { Treatment (Rotifer } \\
\text { denstity, ind./mL) }\end{array}$ & $\begin{array}{r}\text { Nitrite } \\
(\mathbf{m g} / \mathbf{L})\end{array}$ & $\begin{array}{r}\text { TAN } \\
(\mathbf{m g} / \mathbf{L})\end{array}$ & $\begin{array}{r}\text { Alkalinity } \\
\text { (mg CaCO } / \mathbf{L})\end{array}$ \\
\hline 5 & $1.0 \pm 0.3$ & $0.6 \pm 0.4$ & $112 \pm 12$ \\
10 & $1.1 \pm 0.4$ & $0.7 \pm 0.4$ & $115 \pm 16$ \\
15 & $1.1 \pm 0.2$ & $0.7 \pm 0.5$ & $117 \pm 11$ \\
20 & $1.2 \pm 0.9$ & $0.6 \pm 0.4$ & $114 \pm 15$ \\
25 & $1.1 \pm 0.4$ & $0.7 \pm 0.5$ & $115 \pm 13$ \\
\hline
\end{tabular}

Mean \pm standard deviation

\section{Growth performance of fish}

quality, high temperature, etc. Moreover, the optimal levels of TAN and nitrite less than $1.5 \mathrm{mg} / \mathrm{L}$ were suggested for aquaculture ponds (Tucker, 1998). Khanh (2018) reared the scat juvenile, in which, the nitrite level fluctuated from 2.6 to 3.2, but the fish could archive high survival (>90\%). Therefore, the levels of TAN, nitrite, and alkalinity in this study were in range for the normal development of fish.

\subsubsection{Growth in total length}

The growth in total length of fish was presented in Fig. 1 and Table 4. The larvae with the initial size at 
$2,343 \mu \mathrm{m}$, then reached to $4,009-4,420 \mu \mathrm{m}$ after 11 days of rearing. In which, the fish in treatment of 20 rotifer/mL showed the smallest value of total length $(4,009 \mu \mathrm{m})$, but was not statistically different compared to others $(\mathrm{p}>0.05)$.
After 21 days, the fish length ranged from 7,208 to $8,960 \mu \mathrm{m}$, with DLG value from $243-330 \mu \mathrm{m}$ /day and 5.5-6.7\%/day of SGRL. However, no significant difference in length was observed among treatment.

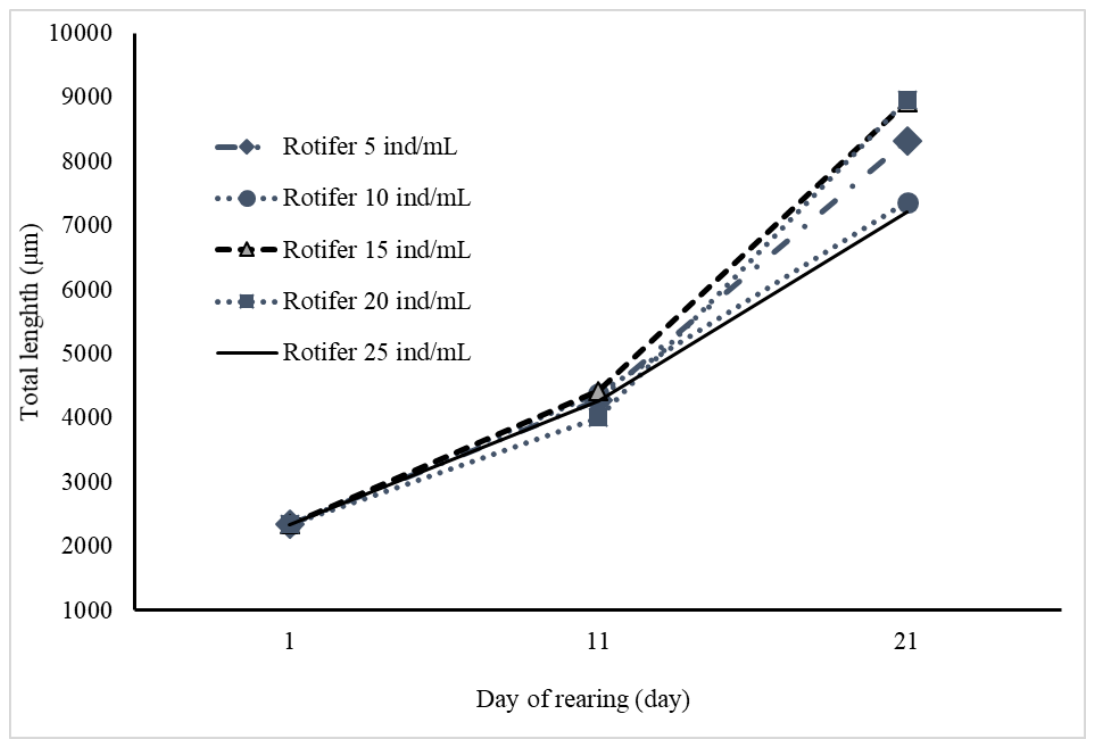

Figure 1. The total length of fish during the experimental period

Table 4. The mean of total length, DLG, SGRL after 21 days

\begin{tabular}{crrrr}
\hline $\begin{array}{c}\text { Treatment (Rotifer } \\
\text { denstity, ind./mL) }\end{array}$ & $\mathbf{L} \mathbf{1}(\boldsymbol{\mu m})$ & $\mathbf{L} \mathbf{2 1}(\boldsymbol{\mu m})$ & DLG $(\boldsymbol{\mu m} / \mathbf{d a y})$ & SGRL $(\% /$ day $)$ \\
\hline 5 & $2,343 \pm 110$ & $8,321 \pm 1,365^{\mathrm{a}}$ & $298 \pm 68^{\mathrm{a}}$ & $6.3 \pm 0.8^{\mathrm{a}}$ \\
10 & $2,343 \pm 110$ & $7,364 \pm 280^{\mathrm{a}}$ & $251 \pm 14^{\mathrm{a}}$ & $5.7 \pm 0.2^{\mathrm{a}}$ \\
15 & $2,343 \pm 110$ & $8,923 \pm 966^{\mathrm{a}}$ & $329 \pm 48^{\mathrm{a}}$ & $6.7 \pm 0.6^{\mathrm{a}}$ \\
20 & $2,343 \pm 110$ & $8,960 \pm 725^{\mathrm{a}}$ & $330 \pm 36^{\mathrm{a}}$ & $6.7 \pm 0.4^{\mathrm{a}}$ \\
25 & $2,343 \pm 110$ & $7,208 \pm 1,844^{\mathrm{a}}$ & $243 \pm 92^{\mathrm{a}}$ & $5.5 \pm 1.4^{\mathrm{a}}$ \\
\hline
\end{tabular}

Mean \pm standard deviation. Means with similar superscripts in the same column are not significantly different ( $p>0.05)$

\subsubsection{Growth in body depth}

The growth in body depth was showed in Fig. 2 and Table 5. In which, the initial body depth was recorded at $821 \mu \mathrm{m}$. After 11 days of rearing, the fish body depth ranged from $1,779-24,420 \mu \mathrm{m}$ and the treatment of 25 ind./mL showed the smallest value of body depth $(1779 \mu \mathrm{m})$. After 21 days, fishes reached 3,437 - 4,911 $\mu \mathrm{m}$, coinciding with DDG at $131-204 \mu \mathrm{m} /$ day and $7.2-8.9 \%$ day of SGRD. However, there was no significant difference among treatments $(\mathrm{p}>0.05)$

Table 5. Growth in body depth of fishes during the rearing time

\begin{tabular}{ccccc}
\hline $\begin{array}{c}\text { Rotifer density } \\
\text { (ind./mL) }\end{array}$ & $\mathbf{D}_{\mathbf{1}}(\boldsymbol{\mu} \mathbf{m})$ & $\mathbf{D}_{\mathbf{2 1}}(\boldsymbol{\mu} \mathbf{m})$ & $\begin{array}{c}\text { DDG } \\
(\boldsymbol{\mu m} / \mathbf{d a y})\end{array}$ & SGRD $(\boldsymbol{\%} / \mathbf{d a y})$ \\
\hline 5 & $812 \pm 85$ & $4,061 \pm 1,055^{\mathrm{a}}$ & $162 \pm 52^{\mathrm{a}}$ & $7.9 \pm 1.3^{\mathrm{a}}$ \\
10 & $812 \pm 85$ & $3,437 \pm 395^{\mathrm{a}}$ & $131 \pm 19^{\mathrm{a}}$ & $7.2 \pm 0.6^{\mathrm{a}}$ \\
15 & $812 \pm 85$ & $4,781 \pm 853^{\mathrm{a}}$ & $198 \pm 43^{\mathrm{a}}$ & $8.8 \pm 0.9^{\mathrm{a}}$ \\
20 & $812 \pm 85$ & $4,911 \pm 1,020^{\mathrm{a}}$ & $204 \pm 51^{\mathrm{a}}$ & $8.9 \pm 1.0^{\mathrm{a}}$ \\
25 & $812 \pm 85$ & $4,114 \pm 1,090^{\mathrm{a}}$ & $165 \pm 54^{\mathrm{a}}$ & $8.0 \pm 1.4^{\mathrm{a}}$ \\
\hline
\end{tabular}

Mean \pm standard deviation. Means with similar superscripts in the same column are not significantly different $(p>0.05)$. 


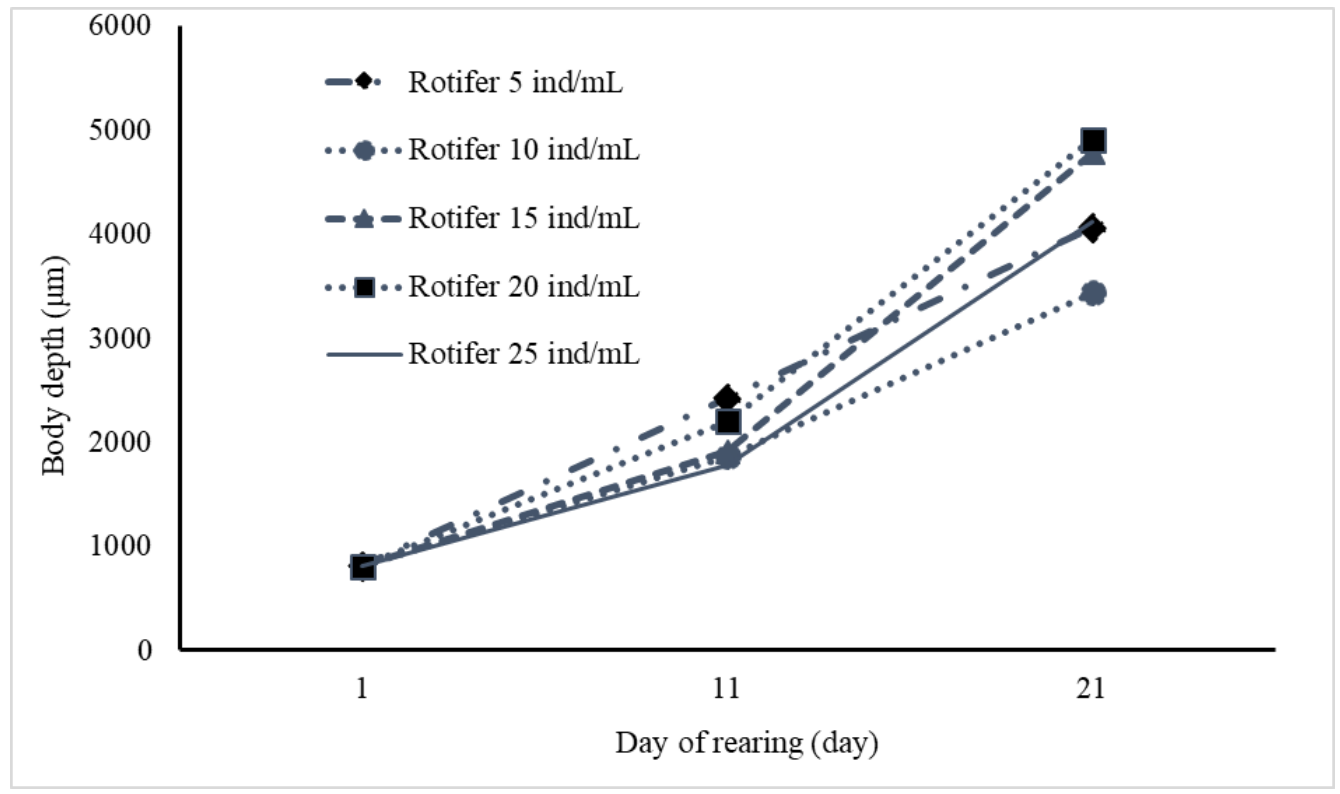

Figure 2. Body depth of spotted scat larvae during the experimental period

\subsection{Survival and biomass of larvae after 21 days}

Figure 3 showed the fish survival and biomass after 21 days of rearing. Accordingly, the survival rate ranged from 15.8 to $48.1 \%$. The highest survival was recorded in the treatments of 10 rotifers/L $(48.1 \%)$ followed by 5 rotifers/L (35.5\%), and was statistically higher than other treatments (15 rotifers $/ \mathrm{mL}(20.5 \%), 20$ rotifers $/ \mathrm{mL}(15.8 \%)$ and 25 rotifers $/ \mathrm{mL}(19.8 \%) .(\mathrm{p}<0.05)$. Similarly, the final biomass of larvae fluctuated from $1.6-4.8$ larva/L, with the highest biomass was in treatment of 10 rotifers/L (4.8 larva/L), 5 rotifers/L (3.5 larva/L) and significantly higher than 15 rotifers $/ \mathrm{mL} \quad(2.1$ larva/L), 20 rotifers $/ \mathrm{mL}(1.6$ larva/L) and 25 rotifers/mL $(2.0$ larva $/ \mathrm{L})(\mathrm{p}<0.05)$.

Most marine fish larvae are visual, and the feeding success of the larvae is dependent of the visibility, prey availability, and the visibility and adequate density of the prey (Houde and Schekter, 1980; Duray et al., 1996). However, high live prey density and residence times could lead to the nutritional deterioration of live feeds, bacterial blooms, and deteriorations of water quality (Vallés et al., 2015; Woolley \& Partridge, 2016). It could help to explain the high mortality of larvae fed high rotifer density. Moreover, high consumption of live feeds would lead to higher production costs (Rabe \& Brown, 2000). The results of this study showed that the spotted scat larvae fed effectively across a wide range of rotifer densities and low prey densities did not negatively affected on larval growth. Rotifers metabolize the nutrients they acquire during enrichment resulting in a deterioration in their nutritional quality over time (Yamamoto et al., 2009), but no significant difference in larval growth was recorded in this study. It was suggested that nutritional depletion was not a significant determinant in the larvae's performance, or Chlorella sp. added to the rearing tanks was sufficient to maintain the nutritional value of the rotifers (Woolley \& Partridge, 2016). Moreover, to be appropriate, the rotifer density should be maintained within a critical threshold and this factor is specific species and age specific, that depended on abiotic factors including light intensity and turbidity (Puvanendran \& Brown, 1999). Carton (2005) reported that yellowtail kingfish larvae required a light intensity at $8 \mu \mathrm{mol} \mathrm{s} \mathrm{s}^{-1} \mathrm{~m}^{-2}$ and $16 \times 10^{4}$ cells $/ \mathrm{mL}$ of algal-induced turbidity levels. Therefore, the light intensity and algal-induced turbidity levels applied for $\mathrm{S}$. arugus larvae need to be investigated to improve the prey ingestion as well as larval performance (Woolley \& Partridge, 2016). 


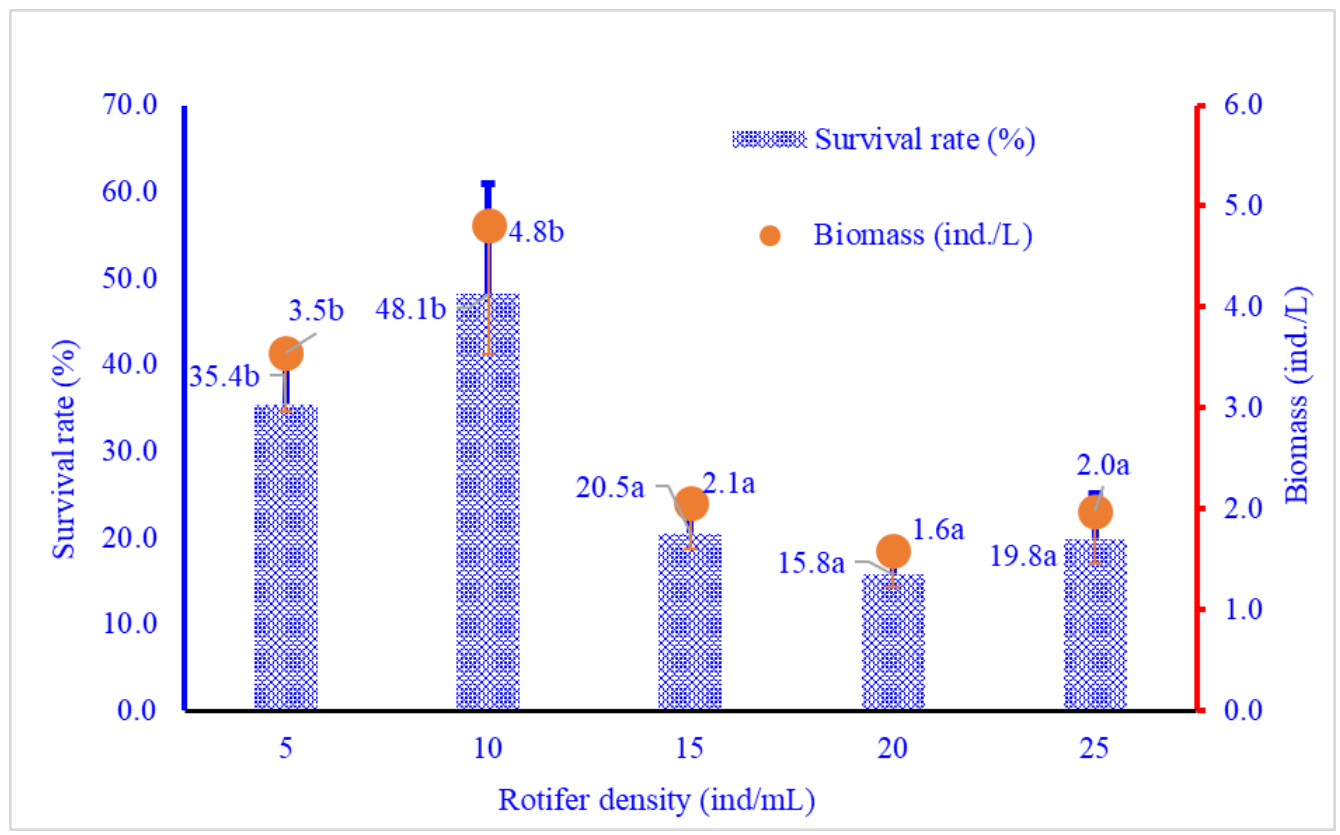

Figure 3. The survival rate and biomass of spotted scat larvae after 21 days of rearing

\section{CONCLUSION}

It could be recommended to use enriched rotifer at 10 ind./mL for S. argus larvae from day 3 to day 15 DAH to achieve high larval survival and performance.

\section{ACKNOWLEDGMENT}

This study is funded by the Can Tho University Improvement Project VN14-P6, supported by Japanese ODA loan.

\section{REFERENCES}

Barry, T. P. \& Fast, A. W. (1992). Biology of the spotted scat (Scatophagus argus) in the Philippines. Asian Fisheries Science, 5, 163-179.

Batty, R. S., Blaxter, J. H. S., \& Richard, J. M. (1990). Light intensity and the feeding behavior of herring, Clupea harengus, Marine Biology, 107, 383-388.

Brest, C. De, Ruyet, J.P.-L., Gaumet, F., Roux, A.L., A.Severe, \& Boeuf, G. (1996). Effects of temperature on growth and metabolism in juvenile turbot. J. Fish Biol, 49, 678-692.

Carton, A.G. (2005). The impact of light intensity and algal-induced turbidity on first feeding Seriola lalandi larvae. Aquaculture Research, 36, 1588-1594.

Claireaux, G., Couturier, C., \& Groison, A.L. (2006). Effect of temperature on maximum swimming speed and cost of transport in juvenile European sea bass (Dicentrarchus labrax). J. Exp. Biol, 209, 3420-3428.

Dhert, P., Rombaut, G., Suantika, G., \& Sorgeloos, P. (2001). Advancement of rotifer culture and manipulation techniques in Europe. Aquaculture, 200(1), 129-146.

Didrikas, T., \& Hansson, S. (2009). Effects of light intensity on activity and pelagic dispersion of fish: Studies with a seabed-mounted echosounder. ICES J. Mar. Sci, 66, 388-395.

Duray, M.N., Estudillo, C.B., \& Alpasan, L.G. (1996). The effect of background color and rotifer density on rotifer intake, growth and survival of the grouper (Epinephelus suillus) larvae. Aquaculture, 146, 217-224.

Gupta, S. (2016). An Overview on Morphology, Biology, and Culture of Spotted Scat Scatophagus argus (Linnaeus 1766). Rev. Fish. Sci. Aquac., 24, 203-212.

Houde, E.D., \& Schekter, R.C. (1980). Feeding by marine fish larvae: developmental and functional responses. Environ. Biol. Fishes, 5, 315-334.

Jayakumar, R \& Nazar, A. K. A. (2013). Marine fish hatchery concept, design and construction. Mandapam regional center of CMFRI, Mandapam camp - 623520, Tamil Nadu, India. 12p.

Kandathil, R. D., AkbarAli, I., Schmidt, B. V., John, E. M., Sivanpillai, S., \& Thazhakot Vasunambesan, S. (2020). Improvement of nutritional quality of live feed for aquaculture: An overview. Aquac. Res., 51(1), 1-17.

Khanh, L.V., Liem, P.T., \& Phuong, N.T. (2014). Food selectivity by spotted scat (Scatophagus argus) larvae. Can Tho University Journal of Science (Special issue: Aquaculture and Fisheries) 145-157 (in Vietnamese). 
Khanh, L.V. (2018). The influence of the difference rate Apex Aqua on growth and survival of Spotted scat (Scatophagus argus). Can Tho University Journal of Science, 54 (Special issue: Aquaculture and Fisheries) (1), $72-77$ (in Vietnamese).

McCarthy, I., Moksness, E., \& Pavlov, D.A. (1998). The effects of temperature on growth rate and growth efficiency of juvenile common wolffish. Aquac. Int., 6, 207-218.

Ni, N.T.T., Anh, N.T.N., Hien, T.T.T., \& Hai, T.N. (2013). Evaluating potential replacement of fishmeal protein by gut weed (Enteromorpha intestinalis) protein in the spotted scat (Scatophagus argus) diets. Can Tho University Journal of Science, 25(B), 83-91 (in Vietnamese).

Puvanendran V., \& Brown J.A. (1999). Foraging, growth and survival of Atlantic cod larvae reared in different light intensities and photoperiods. Aquaculture, 214, 131-151.

Rabe, J., \& Brown, J.A. (2000). A pulse feeding strategy for rearing larval fish: An experiment with yellowtail flounder. Aquaculture, 191, 289-302.

Sim, S. Y., Rimmer, M. A., Toledo, J. D., Sugama, K., Rumengan, I., Williams, K \& Phillips, M. J. (2005). A guide to small-scale marine finfish hatchery technology. NACA, Bangkok, Thailand.

Shao, Y.T., Hwang, L.Y., \& Lee, T.H. (2004). Histological observations of ovotestis in the spotted scat Scatophagus argus. Fish. Sci., 70, 716-718.

Su, M., Duan, Z., Shi, H., \& Zhang, J. (2019). The effects of salinity on reproductive development and egg and larvae survival in the spotted scat Scatophagus argus under controlled conditions. Aquac. Res., 50, 1782-1794.
Tucker, J.W. (1998). The rearing environment. In: Harbor Branch Oceanographic Institution, Florida Institute for Technology, Kluwer Academic publisher. Marine fish culture, 49-146.

Vallés, R., Roque, A., Caballero, A., and Estévez, A. (2015). Use of Ox-Aquaculture $(C)$ for disinfection of live prey and meagre larvae, Argyrosomus regius (Asso, 1801). Aquac. Res., 46, 413-419.

Villamizar, B. Blanco-Vives, H. Migaud, A. Davie, S. Carboni \& F.J. Sánchez-Vázquez. (2011). Effect of light during early larval development of some aquacultured teleosts: A review. Aquaculture, 315, 86-94.

Wikfors, G.H. (2004). Live Feeds in Marine Aquaculture. J. Phycol., 40, 999-1000.

Viet, L.Q., Phu, T.M., Thong, L.V., \& Hai, T.N. (2019). Study on mudskipper (Pseudapocryptes elongatus) culture in tanks at different density in the biofloc systems. Can Tho University Journal of Science, 55(4B), 97-104 (in Vietnamese).

Viet, L.Q., Khanh, L.V., Thong, L.V., Khoa, T.N.D., Kotami, T., \& Hai, T.N. (2020). Effects of stocking densities on growth and survival rates of spotted scat (Scatophagus argus) fingerling reared in earthen ponds. Can Tho University Journal of Science, 2, $87-$ 93 (in Vietnamese).

Woolley, L.D., \& Partridge, G.J. (2016). The effect of different rotifer feeding regimes on the growth and survival of yellowtail kingfish Seriola lalandi (Valenciennes, 1833) larvae. Aquac. Res., 47, 2723-2731.

Yamamoto, T., Teruya, K., Hara, T., Hokazono, H., Kai I., Hashimoto, H., Furuita, H., Matsunari, H. \& Mushiake, K. (2009). Nutritional evaluation of rotifers in rearing tanks without water exchange during seed production of amberjack Seriola dumerili. Fisheries Science, 75, 697-705. 